\title{
Article
}

Peter Trudgill*

\section{Sociolinguistic typology and the speed of linguistic change}

https://doi.org/10.1515/jhsl-2019-0015

\begin{abstract}
Speed of linguistic change is not constant: it differs as between different language and dialects, and between different chronological periods. These differences are, at least to some extent, conditioned by social parameters. Two major social factors are involved in producing these different rates of linguistic change. There is, first, the role of the relative degree of contact versus isolation which speech communities have experienced: a good example is provided by the contrast between Faroese and Icelandic as opposed to the continental Scandinavian languages. There is, secondly, an important role for relative social stability versus social instability in the histories of communities. There is considerable evidence to suggest that conservative language varieties generally tend to be the ones which are relatively more geographically isolated than rapid-change varieties, as well as being relatively more stable as this paper illustrates, through a study of the linguistic consequences of social upheavals involving different historical periods, different continents, and different languages.
\end{abstract}

Keywords: isolation, language contact, linguistic change, social networks, sociolinguistic typology

\section{Introduction}

It is widely acknowledged that linguistic change occurs at different speeds at particular linguistic levels. Syntactic change is relatively slow; while phonological change is relatively rapid, to the extent that it may even be remarked upon by older speakers in a community. Lexical change tends also to be faster than grammatical change.

Within linguistic levels, too, there may be remarkable differences in the rapidity of change. Wichmann and Holman (2009), for example, show that over the world's languages, definite articles tend to be relatively susceptible to change

*Corresponding author: Peter Trudgill, University of Fribourg, Fribourg, Switzerland, E-mail: peter.trudgill@unifr.ch 
while indefinite pronouns are usually much more stable. Wichmann and Holman suggest that in general basic structural features tend to have greater stability than pragmatically sensitive features like evidentials, address terms and politeness phenomena.

In a detailed analysis, Pawley (1970: 355) has also shown that some particular types of grammatical feature are much more resistant to change in Polynesian languages than others. The Proto-Polynesian tense-aspect markers, direction particles, and position markers have been particularly stable, as have the complement pronoun ${ }^{\star}$ ai and the causative prefix ${ }^{\star} f a k a-$. Though not so durable as these, the passive-transitive suffix, the number prefixes ${ }^{\star}$ toko-, ${ }^{*}$ taki- and ${ }^{*}$ tua-, the reciprocal prefix ${ }^{\star} f e$-, and the postposed conjunction ${ }^{\star}$ foki have been fairly stable cross-linguistically; while conjunctions, manner particles and certain other affixes have been least stable. Even within linguistic levels, then, speed of change may differ.

Notice, moreover, that this observation is not contradicted, as its name might suggest, by Kroch's (1989: 200) much more specific “Constant Rate Hypothesis”, because this simply suggests that "when one grammatical option replaces another with which it is in competition across a set of linguistic contexts, the rate of replacement, properly measured, is the same in all of them" (see Kauhanen and Walkden 2018).

\section{Some languages change faster than others}

Much more puzzling than these differential degrees of stability at different linguistic levels is the phenomenon of cross-dialectal and cross-linguistic variability. It is clearly true that different language varieties may change at different speeds. The North Germanic ancestor of the modern Scandinavian languages was a relatively unified language a millennium ago. However, it is not only the case that modern Danish and Icelandic, having descended from this common ancestor, Old Norse, differ considerably from one another to the point that they are no longer mutually intelligible, because of changes which have taken place in the last 1000 years. It is also clear that many more of these changes have taken place in Danish than in Icelandic. Icelandic has preserved more of the structure of Old Norse than its continental counterparts. Within the context of the Indo-European language family, Icelandic and Faroese are often described as being conservative or archaic varieties, while the continental Scandinavian languages Swedish, Norwegian and - especially - Danish are said to be relatively innovating (see Braunmüller 2000) (on stability and change in Icelandic itself, see Sigurdardottir and Eythórsson 2019). 
This pattern of differential speeds of change is repeated even within the same language. In terms of phonology, the English dialects of the southeast of England are generally considerably more innovating than those of Northeastern England and Scotland where, for instance, pre-Great Vowel Shift Middle English-style monophthongal forms such as out /u:t/ and house /hu:s/ can still be heard, although they disappeared from the south of the country via the innovation of diphthongisation several centuries ago (Trudgill 1999). The distinction between $/ \mathrm{M} /$ and $/ \mathrm{w} /$ has been lost in nearly all of England, including in the RP accent, but it still survives as in which versus witch in Scotland, Ireland and Northeastern England; and non-prevocalic / $r$ / has been lost in much of England, but survives in the south-west of the country, as well as in Scotland and Ireland (Trudgill 1999).

An examination of related languages in other language families readily throws up many other examples of sister languages having undergone much more phonological change than others, meaning of course that they have changed faster. For example, it is clear that French, in its descent from Latin, has experienced an enormously greater degree of phonological erosion than related languages such as Italian. The contrast between the development from Latin homo 'man' to Italian uomo /uomo/, as opposed to French on /\%/; from Latin augustum 'August' to Italian agosto /agosto/, as opposed, remarkably enough, to French août /u/; and from Latin unum 'one' to Italian uno /uno/, as opposed to French un /थ̃/, is extremely striking even just in terms of segment loss. Homo and uomo both have four segments, on has one; unum has four segments, uno three, and un one; augustum has seven segments, agosto six, and aout again one ${ }^{1}$ : all that survives of augustum in French is the vowel of the stressed second syllable.

In the Austronesian language family, we can see examples of precisely the same kind of phenomenon - of related languages having changed at very different speeds. If we compare the Polynesian language Tongan with the Micronesian language Puluwatese, which is spoken on Poluwat, a coral atoll in the Chuuk state in the Federated States of Micronesia, we can note precisely this kind of striking contrast. Proto-Oceanic * pituqun 'star' has become Tongan fetu? $u$, as opposed to Puluwatese fu: ; Proto-Oceanic *sakaRu 'reef' is Tongan hakau, as opposed (rather remarkably) to Puluwatese tə: ; and Proto-Oceanic *maqañur is Tongan ma?anu, as opposed to Puluwatese ma:n. In terms of segmental phonology, ${ }^{\star}$ pituqun has seven, feturu has six, and fu: only two; *sakaRu has six segments, hakau five, and të: two; and *maqañur has seven segments, ma?anu six, and ma:n three (Ross et al. 2001).

Amongst Australian languages, we can once again observe precisely the same phenomenon. The Northern Paman languages of Cape York, Northern

1 Or two in the case of the modern spelling-pronunciation /ut/, with restored /t/. 
Queensland, such as Mbiywom, Yinwum, Luthigh, Awngthim and Aritinngithigh are well known to be so-called 'eroding languages' (Butcher, forthcoming), while most of the related Pama-Nyungan languages spoken further south are very much less so. We can note striking contrasts such as those involving Proto-PamaNyungan *calañ 'tongue', which has developed into /talan/ in Bidjara, southwestern Queensland; but has gone to /lan/ in Northern Paman Awngthim; ProtoPama-Nyungan *kami 'grandmother' is still /kami/ in Bidjara, but in Awngthim it has eroded to /mai/; and Proto-Pama-Nyungan *masa 'hand' is /mara/ in Bidjara but in Awngthim it has been eroded to / $\mathrm{Pa} /$ (Butcher, forthcoming).

Languages can also change at very different speeds in terms of maintenance of their phoneme inventories. Proto-Austronesian had 23 consonants, and many modern Austronesian languages have a similar number: Tagalog has 21 consonants; Malay 18; and Rukai (one of the indigenous languages of Taiwan) 20. However, the dispersal over a period of more than 5000 years of the Austronesian language family into the Pacific was accompanied by a remarkable series of phonological developments involving inventories. Two of the Polynesian languages at the end points of this dispersal, Hawai'ian in the far north, and Rurutu, in the far Southern Australs in French Polynesia, have very small inventories indeed. Proto-Polynesian, which dates to around 500 BC-200 AD (Clark 1976; Krupa 1982) had an inventory of 13 consonants:

$\begin{array}{llll}\mathrm{m} & \mathrm{n} & \mathrm{y} & \\ \mathrm{p} & \mathrm{t} & \mathrm{k} & \text { ? } \\ \mathrm{f} & \mathrm{s} & & \mathrm{h} \\ \mathrm{v} & & & \\ & \mathrm{l} & & \\ & \mathrm{r} & & \end{array}$

This was somewhat reduced in Nuclear Polynesian (the ancestor of all modern Polynesian languages except Tongic), which dates to $100 \mathrm{BC}-200 \mathrm{AD}$ (Trudgill 2004a), with a probable homeland being Samoa, through the loss of $/ \mathrm{h} /$, and the merger of /r/ with /1/, giving a system of 11 consonants. In Central Eastern Polynesian, which postdates the eastward expansion of the Polynesian peoples into the more remote areas of the Pacific, which could have been around $500 \mathrm{AD}$ (Kirch and Green 2001), this was further reduced to 10 consonants as a result of the loss of $/ \mathrm{R} /$. This is already a very minimal consonant system, especially bearing in mind that there were only five vowels. Then, however, Hawai'ian from about $1000 \mathrm{AD}$ reduced the consonant system even further to eight by merging $/ \mathrm{f} /$ and $/ \mathrm{s} / \mathrm{as} / \mathrm{h} /$, and merging $/ \mathrm{n} / \mathrm{with} / \mathrm{n} /$. In addition to this, $/ \mathrm{k} /$ became $/ \mathrm{r} /$ and $/ \mathrm{t} /$ changed to $/ \mathrm{k} /$. The Rurutu language of the Austral Islands (Tubuai), situated on the extreme southern fringes of French Polynesia, also developed an extremely attenuated 
consonant system of eight consonants in which the glottal stop had three different historical sources:

$\begin{array}{lll}\mathrm{m} & \mathrm{n} & \\ \mathrm{p} & \mathrm{t} & \text { ? } \\ \mathrm{f} & & \\ \mathrm{v} & & \\ & \mathrm{r} & \end{array}$

\section{Explanations}

It is not altogether clear why this would be. Why does it happen that certain linguistic varieties change faster than others in terms of sound changes, phonetic erosion, and inventory size? "Sound change proceeds at very different rates in different languages" (Blust 2007: 40), and although "given enough time, language change is inevitable ... this inevitability does not explain radical differences in rates of change within any given language family" (2007: 1). Blust does, however, have important insights into this issue. Some languages, he suggests, do seem to have run wild in terms of linguistic change. Compared to other members of the Indo-European language family, Armenian has undergone some remarkable changes: erku and erekh, Blunt points out, are cognate with English two, three. Amongst the Romance languages, French can be characterised in the same way (see above, on phonetic erosion). Blust discusses hot spots of phonological change, and illustrates what he means by this with reference to the Austronesian languages of Borneo (Malaysia and Indonesia). From a phonological point of view, according to Blust, the north-central Borneo languages spoken to the south of Sabah represent a hot spot within the Austronesian language family. "A wide swath of languages extending across northern Sarawak far into Kalimantan show an exuberant efflorescence of phonological innovations" (2007: 2); and these languages demonstrate "disfiguring types of sound change" (2007: 4) which are so considerable that they totally conceal the etymological origin of the items in question, in the manner of Armenian erku from Proto-Indo-European ${ }^{*} d w o-$. For example, Proto-Malayo Polynesian *duha 'two' has given rise to relatively predictable forms in the languages of the Philippines such as dua and duah, while in the hotspot area of Borneo "disfiguring changes" have led to extraordinary but genuinely cognate forms like ba, lugwa and wëh.

Blust then attempts an explanation. He relates the rapid and dramatic linguistic changes that have occurred in this area of northern Sarawak to sociolinguistic typology (Trudgill 2011). Blust argues that, as opposed to simply being “the 
products of phonetic or phonological causation ... some small but not insignificant subset of sound changes may be driven by social forces" (2007: 2). He further suggests that "contact may have played a role" in the genesis of this phenomenon.

Trudgill (2011) goes further than this and asserts that contact is the key factor in leading to higher speed of linguistic change, a picture which also emerges rather strongly from Braunmüller et al. (2014). There are very many cases that one could cite in favour of this claim

\subsection{Scandinavian}

The contrast between the continental and insular Scandinavian languages (see above) supports this argument very appropriately. "The Faroe Islands and Iceland lie far out into the Atlantic Ocean, away from the European mainstream, and have experienced relatively low levels of contact, while the continental Scandinavian languages experienced considerable levels of contact, notably with the Low German of the Hanseatic League" (Trudgill 2011: 6). This claim is supported by Jahr (2001: 100) who writes of the "heavy influence of language contact between Norwegian and Low German” (2001: 100).

\subsection{Arabic}

Ingham (1982: 33) writes that "comparison of the dialects of inner Arabia with those of the outer fringe, namely Mesopotamia and the Gulf, reveals a marked generalisation: that the outer dialects, and more particularly those of Mesopotamia, have reduced a number of contrasts still extant in the dialects of the interior". He continues: "in the main it is more accurate to regard the process as one of simplification"; and, crucially, he observes (1982: 34) that simplification in the dialects of Mesopotamia and the Gulf appears to correlate with contact.

\subsection{Greek}

Modern Greek dialects also illustrate very nicely the thesis that some dialects may be much more conservative than others (Trudgill 2004b). For example, most varieties of Greek lost the classical distinction between geminate and non-geminate consonants probably as early two thousand years ago, in the first century AD, so that for example Ancient Greek /gramma/ 'letter' is now Modern Greek /Crama/. Remarkably, however, two millennia on, geminates are still retained, according to Newton (1968), in the Greek dialects of southern Italy, the Dodecanese islands, the 
island of Chios, Cappadocia in central Asia Minor, and Cyprus (Stability and change in Cypriot Greek itself is very helpfully discussed in Tsipaklou (2014)).

\subsection{Norwegian}

The most conservative dialects of Norwegian are by general consent those found in relatively remote inland valleys and other non-coastal areas, while the most innovating are those in the well-trafficked southern coastal areas. The latter have lost the marking of the dative case on nouns, while the former have retained it. According to Haugen (1976), the dative was probably lost in all of mainland Scandinavia by 1400 in indefinite nouns in the singular and by 1500 in the plural. It survived longer in the definite form of nouns, but has now disappeared from most varieties of mainland Scandinavian, except in some fossilised phrases. However, several centuries later, the dative is still alive and well in the dialects of central Norwegian districts such as Hedmark, Hallingdal, Setesdal and Voss, and the adjacent Swedish dialects of Härjedalen, Jämtland and upper Dalarna, as well as in Västerbotten and Norrbotten. In all these areas, inflected forms of the dative still survive in the definite form of nouns and in pronouns (Haugen 1976: 293; Skjekkeland 1997: 151-4). The link here between these conservative Norwegian and Swedish dialects, on the one hand, and conservative Faroese and Icelandic, on the other, is clearly relative geographical isolation. The conservative varieties of Norwegian and Swedish have traditionally been more isolated than the more innovating communities, and have therefore experienced less contact.

The link between contact, peripherality and speed of change received considerable attention in the work of the school of linguistics arising out of research by Bartoli (e.g. 1945) which was known as "Neolinguistics" or "Spatial Linguistics" (Bonfante 1947). The work of this school was based in part on areal principles such as: (1) If, of two linguistic forms, one is found in isolated areas and the other in areas more accessible, then the former is the older; (2) if, of two linguistic forms, one is found in peripheral areas and the other in central areas, then the former is the older.

\section{Differences between chronological periods}

Rates of change, then, differ as between particular languages and dialects. Interestingly, however, it is also the case that the rate of linguistic change is not constant within particular languages and dialects either: significant differences exist between rates of change at different chronological periods in the history of 
individual varieties. The question "Is the rate of linguistic change constant?" posed by Daniel Nettle (1999) is answered by him in the negative.

Sandøy and Nesse (2016: 96-7) agree. They argue that quantitative analyses show that there were very different rates of change in the structure of the Norwegian language at different periods in the history of Norway between 1250 and 2000: from 1800 onwards there has been relatively little change; most changes took place before 1600; and there was a period of particularly rapid change in the years 1350-1500.

Beaken (1996: 166) also agrees. He writes (1996: 166) that there was a "relatively conservative period" in the late seventeenth and eighteenth centuries in terms of the speed of linguistic change in English, while 1350-1500 was a period of unusually rapid change. He argues, for instance, that the development of the modal verbs can, could, shall, should, will, would, may, might, must as a distinct grammatical class in English happened remarkably rapidly in the years around 1400 (Nevalainen 2002).

Jackson (1953) similarly claims that most of the sound changes which took place in the transition from Brittonic to Welsh, Cornish and Breton occurred between approximately $450 \mathrm{AD}$ and $600 \mathrm{AD}$, a period of only a century and a half. And not only phonology was involved: the linguistic changes which occurred in British were to "alter its whole appearance" and "to modify fundamentally its syntax" (1953: 691). Because of the extraordinary rapidity of this change, Jackson says, "we can be fairly sure that Vortigern around 450 could not have understood Aneirin around 600" (Jackson 1953: 690). This is a most remarkable claim. A contemporary parallel would be to suggest that speakers of, say, English from 2015 would not have been understood by English speakers of 1865 (when my own greatgrandmother, who I frequently conversed with, was born).

Jackson's claim is strengthened, however, by the work of O'Rahilly (1946: 2489) who similarly describes an extremely rapid series of linguistic changes which took place in the transition from Middle Irish to Early Modern Irish at more or less exactly the same period of history. He says that "the fifth and sixth centuries are known to have been a period of unusually rapid development in the Irish language” (O’Rahilly 1976: 495).

\section{Explanations}

This naturally raises the intriguing question as to why languages should change faster at some periods of their history than at others (Breitbarth et al. 2019). Actually, though, it is intuitively rather apparent what one of the major social factors involved here must be. As Labov (1994: 24): says "it is well known that 
catastrophic events have played a major role in the history of all languages, primarily in the form of population dislocations: migrations, invasions, conquests, and massive immigrations”.

In the study of the history of Norwegian, the years of the Black Death are generally taken to be the period during which Old Norse morphed into Middle Norwegian, demonstrating significant morphological simplification (Haugen 1993; Mæhlum 1998; Venås 2002): the social upheaval caused by the plague in Norway was enormous, with some estimates suggesting that as much as two-thirds of the population died (Sandøy and Nesse 2016: 97). Sandøy and Nesse explain that there was very considerable migration in the years after the plague because, amongst other things, there were now many empty farms which could be bought very cheaply. Also in the Late Middle Ages, a new year-round fishing export industry developed, which led to very large numbers of people migrating from inland areas to the coast, particularly in the 1400s. This leads Sandøy and Nesse to argue that "the big linguistic changes which we observe in the Late Middle Ages can therefore hardly be thought of as anything other than the result of koinéisation processes - that is, migration set many linguistic-change tendencies in motion, and created new dialects" [my translation] (Sandøy and Nesse 2016: 97). ${ }^{2}$

Beaken similarly asks (1996: 166) if there is any connection between the "dramatic series of changes" which took place in English, on the one hand, and the "social turmoil and a revolution in personal relations" which took place at the same time: the Hundred Years war; and recurrences of the Plague which "decimated the population, loosened the ties of the feudal order and led to increased social mobility and a shortage of labour". The counter-reaction of the upper classes and the imposition of the Poll Tax then led to the Peasants' Revolt in 1381, and so eventually to the collapse of the old feudal order. Fourteenth century England was a very unstable place. It is true that the English Revolution did not occur until the 1640s, but "the events that led to the overthrow of this old order were shaped long before the Revolution itself”. Beaken then answers his own question by suggesting that "it seems plausible" that there was a connection between this "social turmoil and revolution" and the "dramatic series of changes in the language" (1996: 166).

On the same theme, Raumolin-Brunberg (1998) discusses the linguistic consequences of the English Civil War, which was fought from 1642 to 1649 (see also Nevalainen and Raumolin-Brunberg 2003). This was another period of very considerable turmoil, with tens of thousands of men involved in the fighting, and with most areas of England suffering from an armed conflict which produced very

2 "Dei store språkendringane vi obseverer i seinmellomalderen, kan derfor vanskeleg tenkast som anna enn resultat av koinéiseringsprosessar, dvs. at folkeflyttingar har sett i gang mange endringstendensar og skapt nye dialektar”. 
large numbers of casualties. Over 80,000 soldiers and more than 100,000 civilians lost their lives, which was a higher proportion of deaths per head of population than was suffered by the English - and that almost entirely overseas - during the First World War.

Raumolin-Brunberg (1998) analyses developments in the English pronoun system which occurred against the background of this Civil War, and provides extensive quantitative linguistic evidence for the influence of the social upheaval, from The Corpus of Early English Correspondence. She outlines the major pronominal changes as being:

1. the development of somebody, anybody, everybody, nobody as fully grammaticalised indefinite pronouns.

2. the parallel development of someone, anyone, everyone, no one as fully grammaticalised indefinite pronouns.

3. the appearance of the third-person singular possessive pronoun its, replacing earlier his.

4. the loss of case-marking on the object relative pronoun, with who replacing whom.

Raumolin-Brunberg's (1998) analyses show that the rate of change involving these pronominal developments did accelerate during and immediately after the Civil War, and therefore very likely as a consequence of that conflict.

In the case of the Celtic changes discussed so dramatically by Jackson (1953), we can similarly argue, along with Beaken, that the massive changes in Brittonic which were so rapid that Jackson hypothesises a total loss of mutual intelligibility across a few generations - also occurred when they did precisely because of social turmoil. Much of sixth-century Celtic Britain was a very unstable place indeed, with the Germanic invasions of eastern England leading to conflict, land-taking, dislocation, flight, emigration, and enslavement. This is certainly Jackson's interpretation of the relationship between the social and linguistic events: he writes (1953: 690) that "periods of unusually marked linguistic corruption are sometimes associated with great social upheavals, or with invasion and conquest".

The important role played by social upheaval in producing linguistic change is also confirmed by Bailey et al. (1996), who discuss the relationship between catastrophic events and the speed of change. They examine the role of catastrophes by analysing the effects of the Second World War in Texas and Oklahoma, USA, in terms of linguistic developments. According to them, the key factors which were involved in producing marked and rapid linguistic change in these two neighbouring American states were "rapid acceleration in urban growth, a dramatic expansion of the industrial base, the construction of a large number of military posts (and an influx of federal dollars), and the alteration of patterns of 
migration which had carried massive numbers of Southerners northward and westward for half a century" (1996: 435).

According to Bailey et al. "the population dislocations caused by World War II have had significant linguistic consequences in Texas and Oklahoma, but the consequences are quite complex" (1996: 449). The linguistic geography of the area was significantly altered as a result of the military, political, social, demographic and economic events of the 1940s in that the area of eastern Texas which belonged to the Lower South dialect area, and thus belonged dialectally with neighbouring Louisiana and the other Southern coastal states, grew smaller during the relevant period, with the major isoglosses receding back towards the Louisiana border. But, crucially for our purposes, Bailey et al. also show, using apparent-time data comparing the speech of informants from different age cohorts, that the steepest rise in the rate of the linguistic changes which they investigated occurred precisely during the years of the Second World War and immediately afterwards.

Explanations involving social disturbances of this type have been elevated to a general principle by Dixon (1997), with his proposal of the punctuated equilibrium model, a model which provides a more sophisticated interpretation of the role of social upheavals in linguistic change. The model proposes that languages may exist for very long periods in a state of equilibrium during which relatively little change occurs, until something happens to disturb that equilibrium. Dixon refers to a period of disturbance like this as punctuation. Punctuation is triggered by “some cataclysmic event" (1997: 68), which may be a natural event like a flood or volcanic eruption; or some kind of social disturbance (such as the Anglo-Saxon invasions of England, the English Civil War, or the Second World War); some "striking technical innovation"; or just some movement into new territory. Dixon then concludes that "after the events which caused the punctuation have run their course, a new state of equilibrium will come into being” (1997: 68).

The correct generalisation, then, seems to be that social upheavals of various sorts help to accelerate the rate of linguistic change.

\section{Conclusion}

Two major social factors appear to be implicated in producing different rates of linguistic change. First, there is the role of the relative degree of contact versus isolation of speech communities, as illustrated by the contrast between Faroese and Icelandic, on the one hand, and the continental Scandinavian languages, on the other. Secondly, there is the role of the relative social stability versus instability of communities, as just illustrated through examples of social upheaval from different periods, continents, and languages. There is considerable evidence to 
suggest that conservative language varieties tend generally to be those which are relatively more geographically isolated, as well as relatively more stable socially, than more innovating language varieties. The really interesting question, then, is why this should be the case (Trudgill 2011). Happily, further light is shed on this issue by the other papers in this volume.

\section{References}

Bailey, Guy, Tom Wikle, Jan Tillery \& Lori Sand. 1996. The linguistic consequences of catastrophic events: An example from the American Southwest. In J. Arnold, R. Blake, B. Davidson, S. Schwenter \& J. Solomon (eds.), Sociolinguistic variation: Data, theory and analysis, 435-451. Stanford: CSLI.

Bartoli, Matteo. 1945. Saggi di linguistica spaziale. Turin: Bona.

Beaken, Michael. 1996. The making of language. Edinburgh: Edinburgh University Press.

Blust, Robert. 2007. Òma Lóngh historical phonology. Oceanic Linguistics 46. 1-53.

Bonfante, Giuliano. 1947. The neolinguistic position. Language 23. 344-375.

Braunmüller, Kurt. 2000. Was ist Germanisch heute? Sprachwissenschaft 25(2). 271-295.

Braunmüller, Kurt, Steffen Höder \& Kariline Kühl (eds.). 2014. Stability and divergence in language contact: Factors and mechanisms. Amsterdam: Benjamin.

Breitbarth, Anne, Miriam Bouzouita, Lievan Danckaert \& Melissa Farasyn (eds.). 2019. The determinants of diachronic stability. Amsterdam: Benjamin.

Butcher, Andrew. forthcoming. The sounds of Australian languages. Oxford: Oxford University Press.

Clark, Ross. 1976. Aspects of proto-Polynesian syntax. Auckland: Linguistic Society of New Zealand.

Dixon, R. M. W. 1997. The rise and fall of languages. Cambridge: Cambridge University Press. Haugen, Einar. 1976. The Scandinavian languages. London: Faber.

Haugen, Einar. 1993. Grunnbok i norrønt språk [Introduction to old norse]. Oslo: Gyldendal.

Ingham, Bruce. 1982. Northeast Arabian dialects. London: Kegan Paul.

Jackson, Kenneth. 1953. Language and history in Early Britain. Edinburgh: Edinburgh University Press.

Jahr, Ernst Håkon. 2001. Historical sociolinguistics: The role of Low German language contact in the Scandinavian typological split of the late Middle ages. Lingua Posnaniensis 43. 95-104.

Kauhanen, Henri \& George Walkden. 2018. Deriving the constant rate effect. Natural Language and Linguistic Theory 36. 483.

Kirch, Patrick Vinton \& Roger Green. 2001. Hawaiki, Ancestral Polynesia: An essay in historical anthropology. Cambridge: Cambridge University Press.

Kroch, Anthony. 1989. Reflexes of grammar in patterns of language change. Language Variation and Change 1. 199-244.

Krupa, Victor. 1982. The Polynesian languages. London: Routledge.

Labov, William. 1994. Principles of linguistic change I: Internal factors. Oxford: Blackwell.

Mæhlum, Brit. 1998. Svartedauden - en skjellsettende språkhistorisk begivenhet? [The Black death: A landmark language-historical event?]. Norsk Lingvistisk Tidsskrift 16. 3-32.

Nettle, Daniel. 1999. Is the rate of linguistic change constant? Lingua 108. 119-136. 
Newton, Brian. 1968. Spontaneous gemination in Cypriot Greek. Lingua 20.15-57.

Nevalainen, Terttu. 2002. Mobility, social networks and language change in early modern England. European Journal of English Studies, 4. 253-264.

Nevalainen, Terttu \& Helena Raumolin-Brunberg. 2003. Historical sociolinguistics. London: Longman.

O'Rahilly, Thomas. 1946. Early Irish history and mythology. Dublin: Dublin Institute for Advanced Studies.

O'Rahilly, Thomas. 1976. Irish dialects past and present. Dublin: Institute for Advanced Studies.

Pawley, Andrew. 1970. Grammatical reconstruction and change in Polynesia and Fiji. In Stephen Wurm \& Donald Laycock (eds.), Pacific linguistic studies in honour of Arthur Capell, 301-367. Canberra: Pacific Linguistics.

Raumolin-Brunberg, Helena. 1998. Social factors and pronominal change in the seventeenth century: The Civil War effect? In Jacek Fisiak \& Marcin Krygier (eds.), Advances in English historical linguistics, 361-388. Berlin: Mouton De Gruyter.

Ross, Malcolm, Andrew Pawley \& Meredith Osmond. 2001. The lexicon of Proto Oceanic: The culture and environment of Ancestral Oceanic society Il: The physical environment. Canberra: Pacific Linguistics.

Sandøy, Helge \& Agnete Nesse. 2016. Språkendring [linguistic change]. In Helge Sandøy (ed.), Norsk språkhistorie, vol. I, 31-99. Oslo: Novus.

Sigurdardottir, Sigridur Saeunn \& Thórhallur Eythórsson. 2019. Stability and change in Icelandic weather verbs: Syntax, semantics and argument structure. In Anne Breitbarth, Miriam Bouzouita, Lievan Danckaert \& Melissa Farasyn (eds.), The determinants of diachronic stability, 69-99. Amsterdam: Benjamin.

Skjekkeland, Martin. 1997. Dei norske dialektane: tradisjonelle særdrag i jamføring med skriftmåla [Norwegian dialects: traditional features as compared to the written language]. Kristiansand: Høyskoleforlaget.

Trudgill, Peter. 1999 [1990]. The dialects of England, 2nd edn. Oxford: Blackwell.

Trudgill, Peter. 2004a. Linguistic and social typology: The Austronesian migrations and phoneme inventories. Linguistic Typology 8. 305-320.

Trudgill, Peter. 2004b. The impact of language contact and social structure on linguistic structure: Focus on the dialects of modern Greek. In Bernd Kortmann (ed.), Dialect meets typology: Dialect grammar from a cross-linguistic perspective, 435-451. Berlin: Mouton De Gruyter.

Trudgill, Peter. 2011. Sociolinguistic typology: Social determinants of linguistic complexity. Oxford: Oxford University Press.

Tsipaklou, Stavroula. 2014. Does convergence generate stability?: The case of the Cypriot Greek koiné. In Kurt Braunmüller, Steffen Höder \& Kariline Kühl (eds.), Stability and divergence in language contact: Factors and mechanisms, 163-178. Amsterdam: Benjamin.

Venås, Kjell. 2002. Previous attempts at establishing periods in Nordic language history. In Oskar Bandle (ed.), The Nordic languages: An international handbook of the history of the North Germanic languages, 31-38. Berlin: de Gruyter.

Wichmann, Søren \& Eric W. Holman. 2009. Assessing temporal stability for linguistic typological features. Munich: Lincom Europa. 